\title{
Diagnosis Dengue melalui Deteksi Antibodi Imunoglobulin G Spesifik dalam Sampel Urine dengan Teknik ELISA
}

\author{
Diagnosis of Dengue Through Imunoglobulin G Specific Antibody Detection in Urine \\ Sample with ELISA Method
}

\author{
Acivrida Mega Charisma ${ }^{1 *}$, Elis Anita Farida ${ }^{1}$, Farida Anwari ${ }^{1}$ \\ 1STIKES Rumah Sakit Anwar Medika, Jl. By Pass Krian KM 33 Sidoarjo, Jawa Timur
}

\begin{abstract}
Dengue is a disease caused by dengue virus infection. Diagnosis of the disease is often difficult to be upheld just by the symptoms. Therefore, laboratory diagnostics is required. The general objective of this study was to detect dengue IgG in serum samples with rapid tests and in urine samples of suspected dengue patients using ELISA. The procedure of this study consisted of three stages. First, collecting urine samples from healthy individuals and collecting blood and urine samples from suspected dengue patients; second, examining dengue IgG in serum samples of suspected dengue patients with rapid tests; and third, examining dengue-specific IgG in urine samples from suspected dengue patients and from healthy individuals with ELISA technique. Data analyzed using experimental analytics to determine the cut off point used to interpret laboratory diagnostic results. The results showed that patients with positive serum dengue IgG test at the same time also showed positive results on the examination of dengue-specific IgG in their urine samples while patients with negative serum at the same time showed negative results on the examination of denguespecific IgG in urine samples. Dengue-specific IgG examination in urine samples with ELISA technique can be used as an alternative examination in establishing the diagnosis of dengue, in which urine samples are taken from patients with more than 4 days fever.
\end{abstract}

Keywords: Dengue, IgG, Urine, ELISA

\begin{abstract}
Abstrak. Dengue merupakan penyakit yang disebabkan virus dengue. Diagnosis penyakit ini sering sulit ditegakkan jika hanya melihat dari gejala. Oleh karena itu, diperlukan pemeriksaan laboratorium untuk penegakkan diagnosis. Tujuan umum penelitian ini adalah untuk mendeteksi IgG dengue dalam sampel serum dengan rapid tes dan pada sampel urine pasien terduga dengue dengan menggunakan metode ELISA. Prosedur penelitian ini terdiri dari tiga tahap. Pertama, pengumpulan sampel urine individu sehat dan pngumpulan sampel darah dan urine pada pasien terduga dengue; kedua, pemeriksaan IgG dengue dalam sampel darah pasien terduga infeksi dengue dengan rapid tes; dan ketiga, pemeriksaan IgG spesifik dengue pada sampel urine pasien terduga dengue dengan teknik ELISA, yang sebelumnya sudah dikelompokkan sesuai dengan hasil pemeriksaan IgG dengue pada sampel serum dengan rapid tes, dan pemeriksaan IgG spesifik dengue sampel urine individu sehat dengan teknik ELISA. Analitik eksperimental digunakan untuk menentukan cut off dari data yang kemudian digunakan untuk menafsirkan hasil diagnostik laboratorium. Hasil penelitian menunjukkan bahwa pada pasien dengan hasil pemeriksaan IgG dengue serum positif menunjukkan hasil positif juga pada pemeriksaan IgG spesifik dengue pada sampel urinnya, sedangkan pada hasil pemeriksaan serum yang negatif menunjukkan hasil negatif pula pada pemeriksaan IgG spesifik dengue di sampel urinnya. Pemeriksaan IgG spesifik dengue pada sampel urine dengan teknik ELISA dapat digunakan sebagai pemeriksaan alternatif dalam penegakan diagnosis dengue, di mana sampel urine diambil dari pasien dengan demam lebih dari 4 hari.
\end{abstract}

Kata Kunci: Dengue, IgG, Urine, ELISA

Naskah masuk: 16 Oktober 2019 | Revisi: 16 April 2020 | Layak terbit: 15 Mei 2020

*Corresponding author. E-mail: acie.vrida@gmail.com | Phone : +62 85855778561 


\section{PENDAHULUAN}

Dengue masih merupakan masalah kesehatan terutama di negara tropis atau subtropis karena sering menimbulkan kejadian luar biasa (KLB). ${ }^{1}$ Dengue ditularkan melalui gigitan nyamuk Aedes aegypti dan Aedes albopictus. Virus dengue berkembang biak dalam tubuh nyamuk yang ditularkan pada manusia. ${ }^{2}$

Kasus Demam Berdarah Dengue (DBD) di Kabupaten Kediri pada tahun 2015 berjumlah 702 orang dengan kematian 7 orang setelah itu, kasus DBD mengalami kenaikan pada tahun 2016 dengan jumlah kasus 993 orang dengan kematian 18 orang. Kejadian DBD pada tahun 2017 berjumlah 279 orang dengan jumlah kematian 7 orang sedangkan kenaikan terjadi pada tahun 2018, jumlah kasus DBD sebanyak 486 orang dengan kematian 9 orang. Salah satu dari 38 Kabupaten/Kota yang ada di Jawa Timur adalah Kabupaten Kediri yang tergolong Kejadian Luar Biasa (KLB). ${ }^{3}$

Diagnosis dengue sedini mungkin sangat penting untuk mencegah perkembangan derajat keparahan penyakit ke arah yang lebih serius. Diagnosis dengue sulit ditegakkan pada beberapa hari awal sakit karena gejala yang muncul tidak spesifik dan sulit dibedakan dengan penyakit infeksi lainnya sehingga dapat menyebabkan keterlambatan diagnosis. Penegakan diagnosis dengue selain dengan menilai gejala klinis juga memerlukan pemeriksaan laboratorium sebagai penguat diagnosis.

Pemeriksaan laboratorium untuk diagnosis dengue ada yang bersifat spesifik dan non spesifik. Pemeriksaan yang bersifat spesifik di antaranya berupa isolasi virus/identifikasi virus dan pemeriksaan serologi. Pemeriksaan serologi dapat berupa uji hambatan hemaglutinasi yaitu Human Aglutination Inhibitor (HAI) dan pemeriksaan antibodi imunoglobulin $M$ dan G (IgM dan IgG) melalui teknik ELISA. Pemeriksaan yang bersifat non spesifik misalnya berupa pemeriksaan hematologi dan radiologi. ${ }^{4}$

Pemeriksaan imunologi IgG/IgM dengue merupakan salah satu parameter penting dalam diagnosis dengue. Antibodi yang terbentuk pada dengue adalah antibodi netralisasi, anti hemaglutinin, dan anti komplemen untuk mengelompokkan infeksi DBD primer dan sekunder. ${ }^{5}$

Penelitian ini menggunakan sampel urine dalam pemeriksaan IgG dengue, karena sampel urine mudah didapat. Antibodi IgG merupakan substansi yang diidentifikasi sebagai molekul serum yang mampu menetralkan sejumlah mikroorganisme penyebab infeksi sehingga dapat memberikan imunitas yang tinggi. Selain itu, IgG paling mudah menembus saluran darah dan berdifusi ke dalam jaringan ekstravaskuler dan melakukan aktivitas antibodi di jaringan. Oleh karena itu, IgG dapat ditemukan dalam berbagai cairan, antara lain dalam cairan serebrospinal (CSS) dan urine. ${ }^{6}$

Berdasarkan latar belakang yang disebutkan diatas, peneliti mencoba mencari alternatif bahan pemeriksaan atau sampel lain dari penderita yang dapat digunakan sebagai bahan pemeriksaan untuk menegakan diagnosis infeksi dengue. Penggunaan saliva dalam deteksi IgG, IgM, dan IgA spesifik dengue untuk penegakan diagnosis sudah dilakukan pada beberapa penelitian. Dalam penelitian kali ini peneliti menggunakan sampel urine untuk deteksi IgG spesifik dengue sebagai alternatif dalam penegakan diagnosis dengue.

Tujuan umum penelitian adalah untuk mendeteksi IgG dengue pada sampel urine pasien yang terinfeksi dengue dengan teknis ELISA. Pada pemeriksaan ini metode ELISA yang digunakan adalah metode ELISA Indirek hal ini di karenakan tujuan dari pemeriksaan adalah deteksi atau determinasi antibodi dalam sampel. ${ }^{7}$ Sedangkan tujuan khusus adalah mendapatkan gambaran hasil pemeriksaan IgG dengue urine pada sampel dengan hasil pemeriksaan IgG dengue serum positif, dan hasil pemeriksaan IgG dengue urine dalam sampel dengan hasil pemeriksaan IgG dengue serum negatif.

\section{BAHAN DAN METODE}

Metode penelitian ini adalah analitik eksperimental. Penelitian dilakukan dengan persetujuan Komisi Etik Penelitian Kesehatan RSUD Kabupaten Sidoarjo No. 893.3/1832 /438.6.7/2019. Penelitian ini terdiri dari tiga tahap, sebagai berikut.

\section{Pengumpulan Sampel Darah dan Urine}

Subjek penelitian yang pertama adalah pasien terduga dengue yang masing-masing diambil sampel serum dan urine. Pemilihan subjek dilakukan dengan teknik consecutive sampling yang dilakukan di laboratorium, Unit Gawat Darurat (UGD), rawat inap, dan rawat jalan Klinik Rawat Inap Vita Medika Kepung Kediri. Kriteria inklusi dalam penelitian ini adalah pasien dengan demam lebih dari 4 hari, catatan medik lengkap, dan bersedia menjadi responden. Jumlah pasien yang menjadi subjek dalam penelitian ini berjumlah 68 pasien.

Subjek individu sehat diambil sampel urine, Sampel ini akan digunakan sebagai kontrol 
negatif, kemudian hasilnya dijadikan dasar dalam penentuan nilai cut off. Pemilihan dan pengambilan sampel dilakukan secara serentak di lingkungan klinik dengan kriteria inklusi pada saat pengambilan sampel subjek dalam kondisi sehat, tidak tanda-tanda keluhan atau gejala klinis yang sedang dialami, dan secara makroskopis urine responden tidak menunjukkan adanya kelainan seperti keruh, pekat, dan berwarna tidak normal. Subjek individu sehat berjumlah 22 orang.

\section{Pemeriksaan IgG Dengue pada Sampel Serum dengan Metode Rapid Test}

Sampel darah untuk tes IgG dengue dimasukkan dalam tabung tanpa antikoagulan, kemudian disentrifugasi dengan kecepatan 1500-2000 rpm selama 15-20 menit sehingga didapatkan serum. Serum diteteskan ke dalam sumur pada reagent cassette IgG/IgM rapid test merk Answer Dengue IgG/IgM Combo Rapid Test (CTK Biotech Inc.) sebanyak 5 mikron serum pada lubang/wadah S kemudian ditambahkan 3 tetes buffer pada lubang/wadah B. Hasil dapat dibaca setelah 25 menit dengan inteprestasi negatif jika terdapat 1 garis di area kontrol. Hasil diinterpretasikan positif jika terdapat garis di area kontrol (C) serta pada area IgG (G) dan atau IgM (M). Namun, jika terlihat 1 garis pada area tes maka tes invalid (diulang dengan device baru).

\section{Pemeriksaan IgG Spesifik Dengue dalam Urine dengan Teknik ELISA}

Sebelum dilakukan pemeriksaan ini, sampel dikelompokkan menjadi 3 kelompok yaitu kelompok sampel urine individu sehat (kontrol negatif), kelompok sampel urine responden dengan hasil pemeriksaan IgG rapid test positif, dan kelompok sampel urine responden dengan hasil pemeriksaan IgG rapid tes negatif. Persiapan dan perlakuan sampel serta prosedur pemeriksaan sama untuk semua kelompok, yaitu sampel urine dimasukkan dalam tabung dan disentrifugasi dengan kecepatan 2000-3000 rpm selama 10 menit, lalu supernatan dipisahkan ke dalam microtube.

Semua sumur pada plate direndam dengan larutan pencuci selama 5 menit, kemudian dibuang dan dikeringkan. Setelah itu, urine diencerkan sebanyak 10x, yaitu dengan mencampurkan $1000 \mu \mathrm{l}$ diluent dengan $100 \mu \mathrm{l}$ sampel urine. Kemudian $100 \mu \mathrm{l}$ urine yang telah diencerkan dimasukkan dalam sumur pada plate dan diinkubasi selama 60 menit. Sumur dicuci dengan larutan pencuci 3 kali, setelah pencucian ketiga didiamkan dulu 5 menit, kemudian dibuang dan dikeringkan. Setelah itu, $100 \mu \mathrm{l}$ enzim konjugat ditambahkan ke dalam sumur, kemudian sumur ditutup dengan selotip dan dibiarkan selama 30 menit. Setelahnya, selotip dilepas lalu sumur dicuci lagi dengan larutan pencuci sebanyak 3 kali. Setelah pencucian ketiga, dibiarkan dulu 5 menit lalu dibuang dan dikeringkan. Selanjutnya $100 \mu \mathrm{l}$ substrat ditambahkan ke dalam sumur dan ditutup kembali dengan selotip kemudian dibiarkan selama 10 menit. Langkah terakhir, selotip dilepas dan ditambahkan $100 \mu \mathrm{l}$ stop solution kemudian dibiarkan sampai terbentuk warna kuning. Selanjutnya membaca absorbansi dengan alat ELISA Reader.

Data dianalisis dalam bentuk tabel untuk menentukan nilai mean dan standar deviasi yang akan digunakan dalam penentuan nilai cut off sampel urine. Cara menghitung nilai cut off yaitu:

\section{Nilai cut off : Rata-rata OD + 2 (Standar Deviasi) \\ Keterangan: \\ OD : Optical Density}

Nilai OD cut off digunakan sebagai dasar untuk interprestasi hasil pemeriksaan IgG dengue sampel urine. Sampel urine IgG dengue diinterpretasikan sebagai positif atau negatif berdasarkan nilai OD cut off dengan ketentuan:

1. Negatif, jika nilai OD sampel $\leq$ nilai OD cut off,

2. Positif, jika nilai OD sampel $>$ nilai OD cut off.

Pada tahap berikutnya, data dikelompokkan lagi berdasarkan hasil interpretasi pemeriksaan IgG dengue pada urine dan lamanya hari demam responden saat pengambilan sampel. Sampel yang menunjukkan hasil negatif pada pemeriksaan serum IgG dengue (kelompok non dengue), nilai absorbansi pemeriksaan IgG ELISA pada sampel urinnya digunakan sebagai pembanding.

\section{HASIL}

\section{Pemeriksaan Sampel Serum Rapid Test}

Pemeriksaan sampel serum menggunakan rapid test menunjukkan bahwa 49 sampel (72\%) positif IgG dengue sedangkan 19 sampel (28\%) sisanya menunjukkan hasil negatif.

Tabel 1 menunjukkan bahwa hasil pemeriksaan rapid test IgG dengue pada sampel serum yang menunjukkan hasil positif, paling banyak pada pemeriksaan sampel yang diperoleh pada responden dengan demam hari ke-6 yaitu sebanyak 33 sampel (68\%) dan paling sedikit diperoleh pada sampel yang diambil pada demam hari ke-5 (8\%). 
Tabel 1. IgG Dengue Serum Rapid Test Positif Berdasarkan Lama Hari Demam

\begin{tabular}{ccc}
\hline Lama Hari & \multicolumn{2}{c}{ IgG Dengue Serum Positif } \\
\cline { 2 - 3 } Demam & $\mathbf{n}$ & $\mathbf{\%}$ \\
\hline 5 & 4 & 8 \\
6 & 33 & 68 \\
7 & 6 & 12 \\
8 & 6 & 12 \\
\hline Total & $\mathbf{4 9}$ & $\mathbf{1 0 0}$ \\
\hline
\end{tabular}

Tabel 2 menunjukkan bahwa dari 19 responden dengan hasil pemeriksaan IgG dengue serum rapid test negatif, didapatkan 15 responden $(78 \%)$ dengan demam hari ke-5, serta 2 orang (11\%) pada demam hari ke-6 dan 7. Namun, tidak ditemukan responden dengan hasil negatif pada demam hari ke-8.

Tabel 2. IgG Dengue Serum Rapid Test Negatif Berdasarkan Lama Hari Demam

\begin{tabular}{crc}
\hline Lama Hari & \multicolumn{2}{c}{ IgG Dengue Serum Negatif } \\
\cline { 2 - 3 } Demam & $\mathbf{n}$ & $\mathbf{\%}$ \\
\hline 5 & 15 & 78 \\
6 & 2 & 11 \\
7 & 2 & 11 \\
8 & 0 & 0 \\
\hline Total & $\mathbf{1 9}$ & $\mathbf{1 0 0}$ \\
\hline
\end{tabular}

\section{Perhitungan dan Penentuan Nilai Cut Off}

Nilai cut off diperoleh dari perhitungan berikut:

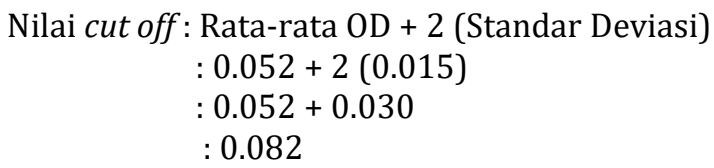

Nilai rata-rata kadar OD didapatkan dari sampel urine individu normal/sehat. Hasil perhitungan mendapatkan nilai cut off sebesar 0,082 dan ditentukan sebagai nilai cut off negatif.

Tabel 3 menunjukkan bahwa kadar nilai OD ELISA terkecil sampel positif $(0,089)>$ nilai OD cut off $(0,082)$. Hasil ini menunjukkan bahwa dari responden dengan hasil pemeriksaan IgG dengue serum rapid test positif, di dalam sampel urinnya juga menunjukkan hasil positif/terdeteksi adanya IgG spesifik dengue.

Tabel 4 menunjukkan kadar nilai OD ELISA urine rata-rata pada sampel dari responden dengan IgG serum negatif < nilai OD cut off $(0,082)$. Hasil ini menunjukkan dari responden dengan hasil pemeriksaan IgG dengue rapid test serum negatif, ternyata juga menunjukkan hasil negatif/tidak terdeteksi adanya IgG spesifik dengue pada urine.

Tabel 3. Kadar OD ELISA sampel Urine dengan Hasil Pemeriksaan IgG Dengue Positif

\begin{tabular}{ccc||ccc}
\hline Responden & Umur (th) & Kadar OD & Responden & Umur (th) & Kadar OD \\
\hline 1 & 12 & 0,230 & 26 & 12 & 0,195 \\
2 & 40 & 0,180 & 27 & 17 & 0,223 \\
3 & 20 & 0,337 & 28 & 21 & 0,160 \\
4 & 21 & 0,165 & 29 & 9 & 0,095 \\
5 & 36 & 0,117 & 31 & 0,467 \\
6 & 30 & 0,162 & 32 & 32 & 0,237 \\
7 & 8 & 0,158 & 33 & 15 & 0,120 \\
8 & 16 & 0,370 & 34 & 12 & 0,220 \\
9 & 12 & 0,160 & 35 & 34 & 0,435 \\
10 & 28 & 0,098 & 36 & 16 & 0,226 \\
11 & 58 & 0,096 & 37 & 58 & 0,218 \\
12 & 26 & 0,142 & 38 & 10 & 0,145 \\
13 & 19 & 0,089 & 39 & 6 & 1,770 \\
14 & 15 & 0,230 & 40 & 8 & 0,292 \\
15 & 51 & 0,198 & 41 & 8 & 0,146 \\
16 & 10 & 0,092 & 42 & 9 & 0,117 \\
17 & 18 & 1,363 & 43 & 42 & 0,230 \\
18 & 8 & 0,115 & 44 & 40 & 0,113 \\
19 & 12 & 0,274 & 45 & 38 & 0,099 \\
20 & 5 & 0,132 & 46 & 21 & 0,246 \\
21 & 9 & 1,148 & 47 & 16 & 0,380 \\
22 & 8 & 0,174 & 49 & 10 & 0,412 \\
23 & 18 & 0,130 & & 0,093 \\
24 & 18 & 1,201 & 0,289 & & \\
25 & 8 & & & & \\
\hline
\end{tabular}


Tabel 4. Kadar OD ELISA Sampel Urine dengan Hasil Pemeriksaan IgG Dengue Negatif

\begin{tabular}{ccc||ccc}
\hline Responden & Umur (th) & Kadar OD & Responden & Umur (th) & Kadar OD \\
\hline 1 & 6 & 0,021 & 11 & 14 & 0,036 \\
2 & 5 & 0,040 & 12 & 16 & 0,042 \\
3 & 9 & 0,050 & 13 & 18 & 0,056 \\
4 & 17 & 0,029 & 14 & 26 & 0,060 \\
5 & 37 & 0,045 & 15 & 22 & 0,071 \\
6 & 28 & 0,042 & 16 & 55 & 0,020 \\
7 & 32 & 0,052 & 17 & 39 & 0,030 \\
8 & 16 & 0,075 & 19 & 44 & 0,016 \\
9 & 10 & 0,089 & 27 & 0,048 \\
\hline
\end{tabular}

\section{Pemeriksaan Sampel Urine}

Tabel 5 menunjukkan hasil kadar rata-rata OD ELISA urine tertinggi diperoleh pada sampel responden yang diambil pada lama demam 6 hari $(0,345)$ dan terendah diperoleh dari sampel responden yang diambil pada lama demam 5 hari $(0,109)$.

Tabel 5. Rata-rata Kadar OD ELISA Urine dengan Hasil Pemeriksaan IgG Dengue Positif Berdasarkan Lama Hari Demam

\begin{tabular}{ccc}
\hline $\begin{array}{c}\text { Lama Hari } \\
\text { Demam }\end{array}$ & Jumlah Sampel & $\begin{array}{c}\text { Rata-rata } \\
\text { Kadar OD }\end{array}$ \\
\hline 5 & 4 & 0,109 \\
6 & 33 & 0,345 \\
7 & 6 & 0,174 \\
8 & 6 & 0,135 \\
\hline
\end{tabular}

Tabel 6 menunjukkan kadar OD ELISA Urine terendah diperoleh pada sampel responden dengan lama demam hari ke $5(0,045)$ dengan hasil negatif. Pada penelitian ini tidak didapatkan sampel responden dengan hasil pemeriksaan IgG dengue serum negatif dengan lama demam 8 hari. Sebagai informasi tambahan, dalam penelitian ini di dapatkan responden dengan usia termuda 4 tahun dan tertua 52 tahun.

Tabel 6. Rata-rata Kadar OD ELISA Urine dengan Hasil Pemeriksaan IgG Dengue Serum Negatif Berdasarkan Lama Hari Demam

\begin{tabular}{ccc}
\hline $\begin{array}{c}\text { Lama Hari } \\
\text { Demam }\end{array}$ & Jumlah Sampel & $\begin{array}{c}\text { Rata-rata } \\
\text { Kadar OD }\end{array}$ \\
\hline 5 & 15 & 0,045 \\
6 & 2 & 0,055 \\
7 & 2 & 0,047 \\
8 & 0 & 0,000 \\
\hline
\end{tabular}

\section{PEMBAHASAN}

Pemeriksaan serologi IgG/IgM dengue merupakan satu parameter spesifik penting dalam penegakkan diagnosis dengue. Kedua antibodi ini muncul 5-7 hari setelah infeksi. Hasil negatif bisa saja muncul karena pemeriksaan dilakukan pada awal terjadinya infeksi. IgG yang positif memiliki nilai diagnostik bila disertai dengan gejala yang mendukung terjadi demam berdarah. Pemeriksaan IgG dan IgM ini juga bisa digunakan untuk membedakan infeksi primer atau sekunder. ${ }^{8}$

Infeksi primer terjadi pada pasien tanpa riwayat terkena infeksi virus dengue sebelumnya. Pada pasien ini dapat dideteksi IgG muncul secara lambat dengan titer yang rendah, hingga terkadang tidak terbaca dalam pemeriksaan dengue rapid test, sedangkan infeksi sekunder terjadi pada pasien dengan riwayat paparan virus dengue sebelumnya. Kekebalan terhadap virus dengue yang sama atau homolog muncul seumur hidup. Namun, setelah beberapa waktu bisa terjadi infeksi dengan serotipe virus dengue yang berbeda. Pada awalnya akan muncul antibodi IgG seiring pada masa demam yang merupakan respon memori dari sel imun. Selain itu juga muncul respon antibodi IgG terhadap infeksi virus dengue yang baru. ${ }^{9}$

Jika gambaran serologis menunjukkan adanya infeksi sekunder di mana hanya IgG saja yang terdeteksi maka diagnosis harus didukung dengan melihat klinis dan pemeriksaan hasil laboratorium darah lengkap berdasarkan kriteria WHO. Hal ini dapat terjadi karena IgG pada infeksi sekunder secara signifikan lebih rendah daripada infeksi primer sehingga tidak terdeteksi pada beberapa kasus. Jika IgG amnestik dari infeksi primer meningkat tajam bisa kemungkinan sebagai akibat adanya infeksi oleh serotipe virus dengue yang berbeda. ${ }^{10}$

Dalam penelitian ini didapatkan 68 sampel serum dengan hasil rapid test 49 sampel positif. Dari 49 sampel positif diperoleh sebanyak 10 sampel responden tidak dapat ditentukan infeksi dengue primer atau sekunder karena IgG dan IgM terdeteksi secara bersamaan, infeksi dengue primer atau skunder dapat ditentukan dengan membandingkn titer dari IgG dan IgM. Ratio IgM/IgG $\leq 0,9$ pada fase akut dapat dijadikan prediktor infeksi dengue sekunder. ${ }^{11}$ Adapun 39 sampel responden lainnya diduga merupakan infeksi dengue sekunder karena hanya IgG saja 
yang terdeteksi. Hal ini dapat disebabkan karena titer IgM yang sangat rendah sehingga tidak terdeteksi pada pemeriksaan rapid test. Pada 19 responden menunjukkan hasil rapid test IgM dan IgG negatif, artinya gejala yang timbul disebabkan oleh infeksi lain (nondengue) atau belum terbentuk antibodi sehingga diperlukan pemeriksaan serum kedua pada fase penyembuhan untuk melihat kemungkinan adanya konversi IgM dan IgG yang negatif menjadi positif. Pada penelitian ini tidak ditemukan pasien dengan infeksi primer yang pasti dengan hanya IgM dengue yang positif dan karena penelitian ini hanya membahas tentang IgG, maka keberadaan IgM tidak akan dibahas lebih lanjut.

Pengambilan sampel darah dan urine dilakukan bersama-sama, yaitu setelah demam > 4 hari. Hal ini dimaksudkan agar didapatkan informasi ada tidaknya kesamaan waktu kemunculan awal antibodi IgG dalam serum dan urine pada hari ke 5 - 7 dari awal infeksi.

Pada pemeriksaan serologi untuk diagnosis dengue penentuan waktu pengambilan sampel sangat mempengaruhi hasil pemeriksaan yang didapat. Hal ini dikarenakan keberadaan antigen atau antibodi dengue dalam tubuh memiliki rentang waktu yang khas. Biasanya lama hari demam dijadikan sebagai standar penentuan waktu pengambilan darah pada diagnosis dengue. Kesalahan penentuan waktu pemeriksaan dapat menyebabkan diperolehnya hasil negatif palsu. Hari ke 3-5 demam adalah waktu terbaik melakukan pemeriksaan serologis karena sudah mulai ditemukan pembentukan antibodi. Pada hari ke 0-2 demam, pasien masih berada pada fase demam di mana belum terdapat perubahan hemodinamik dan pembentukan antibodi yang dapat terdeteksi oleh alat pemeriksaan. ${ }^{10}$

Hasil penelitian menunjukkan bahwa hasil pemeriksaan IgG dengue serum positif terbanyak diperoleh pada pemeriksaan yang dilakukan pada demam hari ke-6 dan hasil pemeriksaan IgG dengue serum negatif terbanyak diperoleh pada pemeriksaan yang dilakukan pada demam hari ke-5. Hal ini menunjukkan bahwa timing atau penentuan waktu pengambilan sampel untuk pemeriksaan serologi IgG dengue sangat berpengaruh terhadap hasil yang didapatkan. Hasil ini sedikit berbeda dengan hasil penelitian yang dilakukan oleh peneliti lain yang menunjukkan hasil bahwa hasil pemeriksaan IgG dengue positif diperoleh pada pasien dengan lama demam hari ke-5 meskipun hanya selisih 3,6\% dari persentase responden dengan hasil IgG dengue positif yang diperiksa pada demam hari ke-6. ${ }^{12}$

Pemeriksaan IgG dengue dalam sampel urine belum lazim digunakan, oleh karena itu harus dibuat batasan atau standar hasil yang disebut nilai cut off. Dalam penelitian ini nilai cut off yang digunakan adalah nilai cut off negatif yang diperoleh dari nilai rata-rata OD +2 (nilai standar deviasi). Dalam penelitian ini sampel kontrol negatif diperoleh dari 22 individu sehat secara klinis dan hasil laboratorium yaitu pemeriksaan Darah Lengkap dan Ig G dan Ig M dengue negatif. Hasil perhitungan memperlihatkan nilai OD cut off sebesar 0,082.

Berdasarkan nilai cut off OD ELISA urine $(0,082)$, dapat membedakan sampel urine positif dan negatif IgG dengue yang sesuai dengan hasil pemeriksaan serum IgG dengue menggunakan rapid test. Hasil penelitian sebelumnya menyatakan bahwa IgM, IgA, dan IgG dengue dapat dideteksi atau ditemukan dalam sampel plasma, saliva, dan juga dalam sampel urine. Lebih lanjut dikatakan bahwa penggunaan sampel alternatif, seperti saliva dan urine masih bisa digunakan dalam penegakan diagnosis dengue terutama pada saat sampel darah tidak mudah untuk diperoleh meskipun dengan sensitivitas tidak sebagus dengan sampel plasma/serum. ${ }^{13}$ Tidak diragukan lagi bila sensitifitas dan spesifivitas dari pemeriksaan IgG dengue dengan teknik ELISA lebih bagus dari pemeriksaan dengan rapid tes karena dengan teknik ELISA mempunyai batas nilai atau range yang lebih luas. ${ }^{14}$

Secara umum IgG merupakan komponen utama imunoglobulin serum dengan berat molekul 160.000 dalton. Imunoglobulin G merupakan $80 \%$ dari total antibodi yang terdapat dalam serum orang dewasa normal. Tidak hanya pada orang dewasa, IgG dapat memberikan proteksi utama pada bayi terhadap infeksi selama beberapa minggu pertama setelah lahir. Hal ini dikarenakan IgG dapat menembus jaringan plasenta dan masuk ke dalam peredaran darah fetus selama di kandungan.

Imunoglobulin $\mathrm{G}$ lebih mudah menembus saluran darah dan berdifusi ke dalam jaringan ekstravaskular sehingga dapat melakukan aktivitasnya di dalam jaringan tubuh. IgG dapat melindungi tubuh dari bakteri, virus, menetralkan toksin bakteri dan dapat merangsang sistem komplemen serta meningkatkan efektifitas sel-sel fagosit apabila berikatan dengan antigen. Imunoglobulin G ditemukan dalam berbagai cairan tubuh termasuk di dalam Cairan Serebrospinal (CSS) dan juga urine. Imunoglobulin $G$ merupakan 
imunoglobulin terbanyak dalam darah, CSS dan peritoneal. ${ }^{6}$

Hasil penelitian menyebutkan bahwa kadar OD serum yang menunjukkan hasil pemeriksaan IgG dengue serum positif terbanyak diperoleh dari responden pada hari demam ke-6 dan paling sedikit pada hari demam ke-5. Hasil ini hampir sama dengan hasil yang diperoleh pada penelitian yang dilakukan oleh Andreas dan koleganya. Pada penelitian tersebut hasil pemeriksaan IgG dengue positif dalam sampel urine cukup banyak ditemukan pada responden dengan indikasi demam hari ke 6-7 yaitu dengan persentase $52 \%$ (51 sampel dari total 98). Namun demikian, IgG dengue positif lebih banyak ditemukan pada responden yang diperiksa pada minggu ke 2 setelah infeksi yaitu 75,3\% (64 sampel dari total 85 sampel) diikuti minggu ke 3 dengan persentase $61,7 \%$ (37 sampel dari total 60 sampel). Hasil ini dapat diketahui karena dalam penelitian tersebut dilakukan serial sampling dan mengikuti perkembangan penyakit (prognosis) dari responden sampai 3 bulan setelah infeksi. ${ }^{13}$ Berdasarkan hasil yang diperoleh dalam penelitian ini dapat diketahui bahwa dalam pemeriksaan serologi baik dengan sampel serum ataupun urine, penentuan waktu pemeriksaan sangat penting dan berpengaruh terhadap hasil yang diperoleh.

\section{KESIMPULAN}

Penggunaan sampel urine dalam pemeriksaan IgG spesifik dengue dengan teknik ELISA dapat digunakan sebagai pemeriksaan alternatif dalam penegakan diagnosis dengue, di mana sampel urine diambil dari pasien dengan demam lebih dari 4 hari.

\section{UCAPAN TERIMA KASIH}

Ucapan terimakasih saya ucapkan kepada institusi STIKES Rumah Sakit Anwar Medika dan Laboratorium Klinik Vita Medika Kediri yang telah membantu dan mendukung dalam penelitian ini.

\section{KONTRIBUSI PENULIS}

Peran penulis pada artikel ini yaitu Acivrida Mega Charisma sebagai kontributor utama. Adapun Elis Anita Farida dan Farida Anwari sebagai kontributor anggota. Detail kontribusi penulis dapat dilihat pada rincian berikut:

$\begin{array}{lll}\text { Konsep } & : & \text { AMC } \\ \text { Kurasi Data } & : & \text { AMC }\end{array}$

\begin{tabular}{lll} 
Analisis Data & $:$ & $\mathrm{AMC}$ \\
Pendanaan & $:$ & $\mathrm{AMC}$ \\
Investigasi & $:$ & $\mathrm{EAF}$ \\
Metodologi & $:$ & $\mathrm{AMC}$ \\
Manajemen & $:$ & $\mathrm{FA}$ \\
Proyek & & \\
Sumber Daya & $:$ & $\mathrm{EAF}$ \\
$\begin{array}{l}\text { Pengawasan } \\
\text { Validasi }\end{array}$ & $:$ & $\mathrm{AMC}$ \\
Visualisasi & $:$ & $\mathrm{EAF}$ \\
$\begin{array}{l}\text { Menulis- } \\
\text { Pembuatan Draft }\end{array}$ & $:$ & $\mathrm{AMC}$ \\
$\begin{array}{l}\text { Menulis-Mengkaji } \\
\text { \& Mengedit }\end{array}$ & $:$ & $\mathrm{AMC}$ \\
\hline
\end{tabular}

\section{DAFTAR RUJUKAN}

1 Dian Perwitasari, Jusniar Ariati TP. Kondisi iklim dan pola kejadian berdarah dengue di Kota Yogyakarta tahun 2004 - 2011. Media Penelit dan Pengemb Kesehat. 2015; 25: 243-248.

2 Candra A. Demam berdarah dengue: Epidemiologi, patogenesis, dan faktor risiko penularan. J Aspi. 2010; 2: 110-119.

3 Kesehatan D. Profil Kesehatan Kabupaten Kediri. Dinas Kesehatan Kabupaten Kediri: Kediri. 2018.

4 Wills BA, Oragui EE, Dung NM, Loan HT, Chau NV, Farrar JJ et al. Size and charge characteristics of the protein leak in dengue shock syndrome. J Infect Dis. 2004; 190: 890-818.

5 Changal $\mathrm{KH}$, Raina $\mathrm{AH}$, Raina A, Raina M, Bashir $R$, Latief $M$ et al. Differentiating secondary from primary dengue using IgG to IgM ratio in early dengue: An observational hospital based clinicoserological study from North India. BMC Infect Dis. 2016; 16: 1-7.

6 Musso D, Teissier A, Rouault E, Teururai S, Pina J De, Nhan T. Detection of chikungunya virus in saliva and urine. Virol J. 2016; : 1-4.

7 Hirayama T, Mizuno Y, Takeshita N, Kotaki A, Tajima S, Omatsu T et al. Detection of Dengue Virus Genome in Urine by Real-Time Reverse Transcriptase PCR: a Laboratory Diagnostic Method Useful after. J Clin Microbiol. 2012; 50: 2047-2052. 
8 Luh N, Purnama S, Wirawati I a P. Peranan pemeriksaan serologi pada infeksi virus dengue. E-Jurnal Med Udayana. 2013; 2: 114.

9 Guzman MG, Halstead SB, Artsob H, Buchy P, Farrar J, Gubler DJ et al. Dengue: a continuing global threat. Nat Rev Microbiol. 2010; 8: S7-16.

10 Lidya Trisnadewi, Ni nyoman Wande I nyoman. Pola serologi IgM dan IgG pada infeksi demam berdarah dengue (DBD) di Rumah Sakit Umum Pusat Sanglah, Denpasar, Bali bulan Agustus Sampai September 2014. E-Junal Med. 2016; 5: 1-5.

11 Arhana BNP. Rasio IgM/IgG fase akut untuk menentukan infeksi dengue sekunder. Sari Pediatr. 2016; 8: 2.
12 Indrawan MA, Muhyi A, Leatemia LD. Gambaran hasil pemeriksaan serologis IgM dan IgG Dengue pada anak penderita demam berdarah dengue berdasarkan lama hari demam di RSUD Abdul Wahab Sjahranie Samarinda. J Kedokt Mulawarman. 2018; 5: 23-31.

13 Andries A, Duong V, Ly S, Cappelle J, Kim KS, Try PL et al. Value of routine dengue diagnostic tests in urine and saliva specimens. Negleted Trop Dis. 2015; 25: 230.

14 Suhendro Suwarto, Riyanti Astrid Diahtantri EH. Hubungan antara konsentrasi d-dimer dengan parameter laboratorium kebocoran plasma pada infeksi dengue. J Penyakit Dalam Indones. 2018; 5: 110-115. 